\title{
ГОЛОДОМОР 1932-1933 РР. ЯК ГЕНОЦИД УКРАЇНСЬКОГО НАРОДУ, ОДИН ІЗ НАЙТЯЖЧИХ ЗЛОЧИНІВ ДЕРЖАВНОЇ ПАРТІЇ
}

Матвєєва Л. Г., Тарасенко Л. Б.

у cmammi досліджено одну з найтрагічніших сторінок нашої історії XX століття - Голодомор 1932-1933 рр. Зазначається, що ця спланована проти українського селянства акція повинна була ліквідувати основу української нації і національного відроӘження, унеможливити протистояння радянській владі. За роки непу (1921-1929) українське селянство через свою ментальність та економічні можливості змогло значно відродитися, стало заможним (мірою того часу, звичайно). Але більшовикам потрібно було контролювати ресурси селян, неп було згорнуто, та почалася епоха колективізації, яка супроводжувалася насильницькими хлібозаготовленнями, розкуркулюванням, терором тощо. Найактивніший спротив чинила Україна, яка мала досвід творення власної державності в попередній період. А найбільш дієвим засобом боротьби проти національного руху був терор голодом, «досвід» якого більшовики набули в період голодомору 1921-1923 рр. Наведено приклади наслідків, які мав Голодомор 1932-1933 рр. для нашого народу, звернуто увагу на те, що саме державна партія стала організатором геноциду українців.

Автори відзначають, що остаточну цифру загиблих від голоду встановити дуже важко. Оскільки $\epsilon$ як прямі, так і непрямі людські втрати від голоду. Проте точно відомо, що це мільйони людей. У статmі зазначається, що люди гинули не тому, що бракувало продовольчих ресурсів, а тому, що все вирощене ними збіжжя влада силоміць забрала.

Автори зазначають, що радянська влада намагалася зробити все, щоб викреслити навіть згадки про Голодомор із суспільної свідомості. Більше того, заперечувала сам факт голоду, забороняла відкрито говорити про голод у СРСР. Лише за горбачовської гласності науковці, громадськість отримали змогу повернутися до цієі проблеми та досліджувати ії. Аналіз тих подій переконливо свідчить, що в українському селі мали місце всі елементи політики геноциду, що був свідомо організований державною партією.

Ключові слова: Голодомор 1932-1933 рр., українське селянство, комуністичний режим, геноцид.

Matvieieva L. G., Tarasenko L. B. Great famine of 1932-1933 as a genocide of Ukrainian nation

() Матвєєва Л. Г., Тарасенко Л. Б., 2020 and one of the most serious crimes committed by the communist party

The authors examines one of the most tragic historical periods of the twentieth century - Ukrainian Famine - the Holodomor of 1932-1933. It is noted that it was a planned action against the Ukrainian peasantry to destroy the basis of the Ukrainian nation, eliminate national revival and prevent the opposition to the Soviet government. During the years of NEP (1921-1929), the Ukrainian peasantry due to its mentality and economic opportunities, was able to revive significantly and became wealthy (by the standards of the time, of course). But the Bolsheviks needed to control the resources of the peasants, the NEP was collapsed and the era of collectivization began, which was accompanied with forced grain harvesting, dekulakization, terror, and so on. The most active opposition was made by Ukraine, which had the experience of its own statehood in the previous period. And the most effective means of combating the national movement was famine terror, the experience of which the Bolsheviks gained during the Holodomor of 1921-1923. Famine became a weapon of mass destruction against Ukrainians. Examples of the consequences of the Holodomor of 1932-1933 for our people are given. The attention is drawn to the fact that the party, which was at the head of state, became the organizer of the genocide of Ukrainians.

The authors note that the final number of deaths from hunger is very difficult to establish. Because there are both direct and indirect human losses from hunger. However, it is well known that this is a huge number, millions of people. The article notes that people died not because of lack of food resources, but because the authorities forcibly took away all the grain they grew.

The authors note that the Soviet authorities tried to do everything possible to erase even the mention of the Holodomor from the public consciousness. Moreover, she denied the very fact of the famine and forbade talking openly about the famine in the USSR. Only with Gorbachev's publicity did scientists and the public have the opportunity to return to this problem and study it. Analysis of those events convincingly shows that all elements of the policy of genocide, which was deliberately organized by the state party, took place in the Ukrainian countryside.

Key words: Great Famine, Holodomor of 1932-1933, Ukrainian peasantry, communist regime, genocide. 
Постановка проблеми та іï актуальність. Як ніколи, сьогодні наша держава переживає тяжкі часи, викликані передусім воєнними діями на Донбасі. Наша повсякденність супроводжується політичною, економічною кризами, різким падінням рівня соціального захисту населення та іншими негативними явищами, пов'язаними з ними. Особливо ускладнилося становище сільських мешканців. Українському селянству, яке у своїй історії вже не один раз стикалося зі значними проблемами, вирішувати й сучасні, скоріше за все, доведеться самостійно. Потреба в серйозному осмисленні досвіду минулого з метою врахування та недопущення в майбутньому попередніх прорахунків визначає незгасаючий інтерес дослідників до всебічного, об'єктивно-реалістичного вивчення та висвітлення специфічних особливостей життя селянства в I пол. 30-х рp. XX ст., особливо в 1932-1933 рр., чим і зумовлюється актуальність означеної проблеми.

Серед найжахливіших подій, закарбованих в історичній пам'яті українського народу, називаємо Голодомори. Радянська влада створила їх для нашого народу цілих три: у 1921-1923 рр., 1932-1933 рр. та 1946-1947 рр. Проте, безперечно, найтяжчим за своїми трагічними наслідками демографічними, економічними, морально-психологічними тощо - був Голодомор 1932-1933 рр.

Аналіз останніх досліджень і публікацій. Проблема Голодомору 1932-1933 pp. у сучасній українській і не тільки історіографії досліджувалася й досліджується. До докладного висвітлення іï різних боків зверталися багато дослідників, зокрема А. Безансон [1], В. Василенко [2], В. Васильєв та Л. Віола [3], В. Верстюк, В. Тиліщак та І. Юхновський [4], Н. Івницький [5], С. Кульчицький [6-8] та багато інших науковців. Дослідники радянської історії 30-х років минулого століття сходяться в тому, що в роки голоду сталінська імперія мала досить продуктів харчування. Люди гинули не тому, що бракувало продовольчих ресурсів, а тому, що держава розпорядилася ними так, аби частина громадян втратила до них доступ. Мільйони українських хліборобів померли тому, що все вирощене ними збіжжя Сталін за допомогою своїх прибічників наказав силоміць забрати. Проте із плином часу завдяки кропіткій праці науковців і всіх тих, кому болить чи цікава ця тема, із забуття виринають все нові й нові факти та свідчення про події тих років, особливо це стосується досліджень на регіональному чи місцевому рівнях.

3 огляду на це метою статті $\epsilon$ висвітлення голоду 1932-1933 рр. що, значним чином, був зумовлений антиселянською політикою більшовицької партії та радянської влади, зокрема антиукраїнською спрямованістю їхніх рішень, що й призвело до катастрофічних наслідків.

Виклад основного матеріалу. Найжорстокішим злочином комуністичного режиму проти українського народу був Голодомор 1932-1933 рр. Ця спланована проти українського селянства акція повинна була ліквідувати основу української нації і національного відродження, унеможливити протистояння радянській владі. Сьогодні ми можемо так говорити, оскільки знаємо передісторію Голодомору.

Після Жовтневого перевороту 1917 р. до влади в Росії приходять більшовики. Вони знищили демократичну Українську Народну Республіку, проголошену в 1917 році, та створили в 1919-1920 рр. Українську Соціалістичну Радянську Республіку, дозволивши навіть у 1920-х роках з метою утвердження своєї влади так звану більшовицьку українізацію. Проте до кінця 1920-х років у СРСР ствердився тоталітарний комуністичний режим із суворою суспільною ієрархією. Будь-який прояв незгоди з рішеннями більшовицької партії жорстоко придушувався і карався.

Форсована індустріалізація та суцільна колективізація кінця 1920-х років призвели до невдоволення людей у різних регіонах СРСР. Найактивніший спротив чинила Україна, яка мала досвід власної державності в попередній період. Центром опору більшовицькій політиці стало українське село, оскільки за часів нової економічної політики індивідуальні селянські господарства в українському селі стали доволі заможними.

У 1930 р. в Україні відбулося понад 4 тисячі масових виступів, в яких взяли участь, за оцінками дослідників, 1,2 мільйона осіб. Протести були стихійними та розрізненими. Добре озброєні й підготовлені війська порівняно швидко придушували їх, але опір все одно змусив комуністів призупинити колективізацію [9].

На початку 1930-х комуністичне керівництво усвідомило хисткість свого становища в Україні й ризики національного виступу українства. Щоб «покарати» українців та унеможливити подальший спротив, восени 1932 року комуністи розпочали спеціальну каральну операцію - масовий штучний голод. Тільки прямим геноцидом удалося остаточно приборкати український національний рух, упокорити українське селянство.

Дослідження українських демографів та істориків засвідчують, що найстрашнішим Голодомор був саме в тих регіонах, де Українська революція 
і національний повстанський рух мали найбільшу підтримку, а саме на Поділлі, Київщині, Черкащині, Полтавщині, Слобожанщині [9].

В українському селі мали місце всі елементи політики геноциду. Не посуха, яка у 1931 р. охопила степові райони, була причиною голодомору (у 1934 р. посуха мала спустошливіший характер, однак голоду тоді не було), а цілеспрямована злочинна політика більшовицького керівництва. Такого висновку дотримуються і члени Міжнародної комісії з розслідування голоду в Україні (до їі складу входили провідні юристи світу), яка працювала в 1988-1990 рр.

Проте близько половини валового збору зерна забирала держава (в 1931 р. - близько 40\%, у 1932 р. - 55\%). Спрямовані в села військові частини відбирали в селян останні продукти. У роки Голодомору на східному і північному кордоні тодішньої радянської України виставлялися спеціальні озброєні загороджувальні загони, які не пропускали за їі межі голодних людей. Безпаспортні селяни не мали змоги покидати рідні місця. Рятуючи голодних дітей, вони масово залишали їх у містах. Були поширені випадки канібалізму. Вимирали цілі українські села, зникали присілки й хутори [10].

Ще у 1931 р. Сталін, говорячи про Україну, сказав: «Низка врожайних районів опинилася в стані розорення й голоду». Такими були практичні результати пришвидшеної сталінської колективізації на селі та нав'язування неймовірно завищених планів здачі збіжжя державі [11].

Тобто ще до початку весни 1932 року українські селяни почали голодувати. Керівництво країни отримувало повідомлення з місць про опухлих від голоду дітей, про сім’ї, де їли траву і жолуді, про селян, які покидають будинки в пошуках їжі. У березні медична комісія виявила трупи на вулиці села поблизу Одеси, бо ні в кого не було сил поховати їх [12].

Водночас по хатах почали ходити бригади реквізиторів, створені сільрадами з місцевих активістів. Бригада налічувала сім-десять озброєних чоловіків. Робили обшуки, вилучали збіжжя, в тому числі насіннєвий матеріал і зерно, що призначалося для родини. Забирали також корову, свиней, птицю.

Про неминучий голод селяни говорили відкрито. Голова колгоспу «Ударник» (Одеська область) Іван Малиновський заявив привселюдно на зборах: «Не давайте вивозити хліб, нам доведеться голодувати. У нас ніхто не має права силоміць забирати хліб». Лаврентій Грицин (голова колгоспу села Ставчинець на Вінниччині), коли приїхали машини для вивозу хліба, заборонив їх вантажити, а колгоспникам пояснив: «У нас забирають весь хліб, і ви залишитися голодними». Радикальніше міркував бригадир колгоспу «Велетень», що на Дніпропетровщині, Петро Пойда: «Необхідно організуватися нам, селянам - брати палиці, бити комуністів, бо вони з нас знущаються. Колгоспи - це та сама панщина, тільки в іншій формі». У колгоспі села Головини в Київській області голова Кирило Краснобокий на зборах сказав, указуючи на представника райкому: «Цей чоловік хоче забрати в нас хліб, щоб ми голодували, вимагайте, щоб він негайно залишив наше село». Після цього з ОГПу приїхали арештувати Краснобокого, проте колгоспники чинили опір.

Траплялося, в «проблемні» господарства влада замість незговірливого голови надсилала свою людину, наприклад, у колгосп села Бармашівка на Вінниччині. Але селяни заявили: «Нам не треба чужого!», і вигнали нового керівника.

Серед районної номенклатури, яка мала виконувати вказівки Кремля на місцях, траплялися й порядні люди. Наприклад, заступник голови Старобільського райвиконкому (Донеччина) Недельченко сказав: «План надійшов, заберуть усе, в країні нема правди, а у нас в районі - тим більше. Піду з партії та повернуся назад на виробництво». Аналогічно міркував уповноважений райвиконкому Бодяга (Дніпропетровська область): «Хай у мене заберуть партквиток, хай мене повісять, але колгоспників я в жодному разі без хліба не залишу» [11].

Але більшість місцевих керівників поводилися інакше. У селі Бранцовка на Харківщині голова сільради Зубаха і його заступник Вишневий прийшли до селянина Шевченка, який не виконував план хлібозаготівлі, забрали чотири вози хліба в снопах, два лантухи зі збіжжям, вигнали чоловіка з хати і зламали дах. На хуторі Веселівці тієї ж області запідозрили, що селянин Васюков ховає хліб. У нього забрали 20 пудів жита, а його самого замкнули в коморі сільради. Туди прийшов сільський голова й залізною палицею почав лупцювати Васюкова по голові. У лютому 1933-го ОГПУ фіксує таке: «У січні ц.р. у деяких селах певних районів України зареєстровані продовольчі труднощі. В 4-х районах Київської, в 2-х районах Вінницької, 4-х районах Дніпропетровської і в 2-х районах Донецької області має місце вживання в їжу різних сурогатів, шлункові захворювання, набрякання й окремі випадки голодної смерті» [11]. 
Побачивши безвихідь, селяни почали тікати. 3 довідки ОГПУ «Про масові виїзди із сіл України й оперативні заходи боротьби з ними» від 2 лютого 1933-го: «Зареєстровані села, з яких втекли всі дорослі й працездатні чоловіки». У тому ж документі відзначено: «3 метою припинення виїздів із сіл органами ГПУ прийнято рішучі заходи, які полягають: у категоричній забороні сільрадам видавати будь-які довідки на виїзд; мобілізації агентури і сільського активу на виявлення організаторів виїздів; створення по лінії транспортних органів ГПУ і по районах оперативних заслонів; арештів організаторів і учасників утечі». Тих, кого ловили, переважно повертали назад - вмирати у своєму селі. Певну частину кидали за ґрати, а декого висилали до Казахстану [11].

У доповідних записках обласних начальників ГПУ у березні 1933-го йшлося про таке: «У Ново-Василівському районі відбувається торгівля трупами кішок, собак і м'ясом полеглих коней з боку спекулятивних елементів серед селян. Продажна ціна собаки в середньому 12 руб., м'ясо полеглого коня - 6-8 руб. кг. Розплата в більшості випадків проводиться речами (килимами, одягом та інше)» (Дніпропетровський облвідділ, 5 березня 1933-го). «На ґрунті голоду відзначено 6 випадків людоїдства. $€$ випадки свідомого умертвіння батьком своїх двох дітей через те, що останніх не було чим годувати» (Вінницький облвідділ, 9 березня). «За останній час ми відзначаємо значне зростання трупоїдства і людоїдства. Щодня з районів отримую 10 і більше повідомлень. У ряді випадків людоїдство переходить навіть у звичку» (Київський облвідділ, 12 березня) [11].

Замість того щоб організувати допомогу голодуючим, радянський уряд приймає ще жорсткіші постанови, які тільки доводять, що голод в українському селі був штучно створений більшовицькою владою.

Так, 7 серпня 1932 року вийшла Постанова ВЦВК і РНК СРСР «Про охорону майна державних підприємств, колгоспів і кооперативів та про зміцнення суспільної (соціалістичної) власності» [13], відома в народі під назвою «Закон про п'ять колосків». Окрім власне самого закону, існувала також Таємна інструкція про його застосування.

Закон передбачав як захід судової репресії за розкрадання колгоспного і кооперативного майна «розстріл із конфіскацією всього майна із заміною за пом'якшувальних обставин позбавленням свободи на термін не нижче 10 років з конфіскацією всього майна». Амністія в цих випадках заборонялась. На літо 1933 року за цим законом було засу- джено 150000 осіб. Зокрема, засуджували дітей, які намагалися знайти хоч якусь їжу. Фактично, людям було заборонено їсти.

За кілька днів до того, 4 серпня 1932 р., надіслано лист Й. Сталіна до Л. Кагановича, в якому пропонувалося ОДПУ залучати озброєних осіб для охорони залізничних вантажів (ешелони із зерном) та надавати їм право розстрілювати на місці осіб, які посягнули на розкрадання залізничних вантажів.

Причиною написання цього закону послужило те, що в переджнивні дні з'явилися «несуни». Виснажені голодом селяни крадькома збирали колоски й несли зерно додому в кишенях, за пазухою. Коли про це довідалися в Кремлі, то уряд прийняв спеціальний закон про охорону соціалістичної власності, яким за розкрадання колгоспного майна призначалася «вища міра соціальної відповідальності» - розстріл із конфіскацією всього майна. Тому закон у народі одержав назву «закон про 5 колосків», оскільки часто за ним засуджували селян, що займалися ручною збіркою залишків зерна.

За розкрадання вантажів на залізничному і водному транспорті законом теж передбачався розстріл з конфіскацією майна, який за пом'якшувальних обставин міг бути замінений на позбавлення волі терміном не менше 10 років. За привласнення колгоспної власності передбачалося позбавлення волі терміном від 5 до 10 років з відбуттям покарання в концентраційному таборі. Засуджені за цим законом не підлягали амністії.

Сталін власноручно написав цей закон. У розпалі голодомору, на початку 1933 року, було засуджено 54645 чоловік, з яких через відсутність пом'якшувальних обставин 2110 чоловік - до смертної кари. Суворі санкції цього закону не обумовлювали ні розміри, ні способи «крадіжки". Тобто були створені всі умови для того, щоб влада могла у великих масштабах користуватись цим законом, адже до відповідальності притягувались навіть діти. Закон установив карну відповідальність не лише за «хищение социалистической собственности», а й за агітацію проти колгоспів. За здійснення хоча б одного з цих злочинів позбавляли волі терміном від 5 до 10 років. 11 серпня 1932 р., передбачаючи опозицію не лише селян, але й українських кадрів до закону про «П'ять колосків», Сталін пише до Кагановича: «Якщо не візьмемося тепер за виправлення становища в Україні, то можемо ії втратити». Його турбує непевність 500-тисячної української компартії, в якій «немало гнилих елементів, свідомих 
і несвідомих петлюрівців, прямих агентів Пілсудського». Сталін застерігає: «як тільки справи погіршаться, ті елементи негайно відкриють фронт усередині (i поза) партії, проти партії» [14, с. 277].

11 серпня 1932 р. Сталін у листі Кагановичу вимагав направити спеціального листа ЦК ВКП(б) до партійних і судово-каральних органів про застосування закону про охорону громадської власності та боротьбу проти спекулянтів. Підкреслював, що «найголовніше зараз - Україна», оскільки справи в Україні дуже погані. Повідомлялося, що у двох областях України близько 50-ти райкомів висловилися проти плану хлібозаготівель, визнавши його нереальним. Висловив звинувачення на адресу українських керівників (генерального секретаря ЦК КП(б)У Станіслава Косіора, Власа Чубаря та голови ДПУ УСРР Станіслава Реденса), а також побоювання втратити Україну через підривну діяльність агентури Юзефа Пілсудського та наявність свідомих і несвідомих петлюрівців, а також прямих агентів Пілсудського в ЦК КП(б)У. Пропонував вжити рішучих заходів для виправлення господарської і політичної ситуації в Україні: зняти з посади генерального секретаря ЦК КП(б)У С. Косіора та поставити на його місце Л. Кагановича; висунути на посаду голови українського дПу В. Балицького, пересунувши С. Реденса на посаду заступника; замінити В. Чубаря іншим керівником, наприклад, Г. Гриньком; перетворити Україну в найкоротший строк на фортецю СРСР «і грошей на це не шкодувати» [14, с. 282].

Привертає увагу виокремлення національного чинника в листуванні, тобто використання термінів «українці», «Україна», «українська верхівка», а не ідеологічних тлумачень «соціалістична» чи «радянська» Україна. Особиста причетність Й. Сталіна до формування закону від 7 серпня 1932 р. має безпосереднє відношення до створення карально-репресивної системи позбавлення засобів існування голодних селян, про підміну морально-етичних норм класовими, про державну політику масового винищення людей [15, с. 58].

Аналіз 20-ти тисяч справ показує, що серед засуджених було 83\% колгоспників та селян-одноосібників і лише 15\% - «кулацько-заможних елементів». Отже, цей закон було спрямовано проти селян, котрі, рятуючи дітей від голодної смерті, змушені були нести додому з току чи поля кілограм чи два зерна, ними ж вирощеного [5, с. 278].

Водночас наприкінці літа 1932 р. газета «Правда» організувала в Україні рейд боротьби з крадіжками зерна. 37 по 17 серпня 1932 р. в ньому взяли участь 100 тисяч «ударників преси».

Під час Голодомору 1932-1933 рр. в Україні сталася демографічна катастрофа. Остаточну цифру кількості загиблих від голоду не визначено й досі. Проте це не означає, що не можна назвати конкретну цифру жертв. Кількісні оцінки втрат $\epsilon$, проблема полягає лише в тому, що їх надто багато. Це пояснюється кількома причинами - як технічного, так і політичного характеру.

По-перше, терор голодом $є$ специфічною формою репресій. На політв'язнів заводили справи, тож долю кожного з них досить легко простежити. Жертви ж голоду безіменні. Важко розрізнити загиблих від голоду та спричинених ним хвороб і померлих природною смертю.

По-друге, в охопленій голодом місцевості різко падала народжуваність. Це явище $\epsilon$ наслідком голоду. Отже, потрібно називати дві цифри втрат - прямі й повні. У повних втратах ураховуються й ненароджені.

По-третє, у 1932-1933 рр. у віковій піраміді народонаселення утворилася глибока вищербина. Загиблі від голоду або взагалі ненароджені випали з процесу відтворення народонаселення. Унаслідок цього через покоління у віковій піраміді утворилася нова вищербина трохи меншої глибини. Ще через покоління - ще одна (ненароджені онуки жертв голоду).

По-четверте, багатьом політикам здається, що можна скористатися розмаїттям цифр, щоб вибрати найбільш зручну. Одні збільшують кількість жертв до неможливо високої, інші применшують наслідки голоду аж до безглуздого заперечення самої події. Розглядаючи оцінки, що формуються за різними критеріями, можна осягнути всю глибину цієї складної проблеми. Її не розв'язало відкриття ретельно приховуваної за радянських часів демографічної статистики. у 1932-1933 рр. облік дав цілком зрозумілий збій. Неповна реєстрація в охоплених голодом регіонах пояснювалася тим, що гинули й реєстратори [7].

Висновки. Таким чином, щоб утримати УСРР у кремлівській орбіті, Сталін пропонує перетворити іï «якнайскоріше на твердиню СРСР». І голодомор 1932-1933 рр. був фундаментом геноциду, спробою остаточно покінчити з українським «національним питанням». Голод, який поширювався протягом 1932 р. і набув найстрашнішої сили на початку 1933 р., став наслідком цілеспрямованих дій державної (більшовицької) партії та радянської влади проти населення УСРР. 
Радянська влада намагалася зробити все, щоб викреслити навіть згадки про Голодомор із суспільної свідомості. Більше того, заперечувала сам факт голоду, забороняла відкрито говорити про голод у СРСР. Лише за горбачовської гласності науковці, громадськість отримали змогу повернутися до цієї проблеми та досліджувати іï. Сьогоднішній аналіз тих подій переконливо свідчить, що в українському селі мали місце всі елементи політики геноциду, що був свідомо організований державною партією.

Перспективи подальших досліджень проблеми вбачаються у вивченні місцевих (регіональних) особливостей цих жахливих процесів, які зовсім недавно відбувалися в нашій історії, віднайденні нових фактів, що свідчили би про злочини тоталітарного режиму під час Голодомору 1932-1933 рр. в Україні.

\section{Література}

1. Безансон А. Лихо століття. Про комунізм, нацизм та унікальність голокосту. Київ : Університетське видавництво Пульсари, 2007. $136 \mathrm{c}$.

2. Василенко В. Голодомор 1932-1933 годов в Украине как преступление геноцида. Правовая оценка. Київ : Вид-во ім. О. Теліги, 2009. 48 с.

3. Васильєв В., Віола Л. Колективізація і селянський опір на Україні (листопад 1929-березень 1930 рр.). Вінниця : Логос, 1997. 536 с.

4. Верстюк В., Тиліщак В., Юхновський І. Голодомор. Геноцид українського народу, 1932-1933. Київ : Вид-во ім. О. Теліги, 2008. 25 с.

5. Ивницкий Н. Репрессивная политика советской власти в деревне (1928-1933 гг.) ; РАН. Ин-т рос. истории ; Университет г. Торонто (Канада). Москва, 2000. 350 с.

6. Кульчицький С. Голод 1932-1933 рр. в Україні як геноцид: мовою документів, очима свідків ; НАН України. Інститут історії України. Київ : Наш час, 2008. 239 c.

7. Кульчицький С.В. Голодомор 1932-1933 рр. як геноцид. Труднощі усвідомлення. Київ : Наш час, 2007. 424 c.

8. Кульчицький С. Почему он нас уничтожал? Сталин и украинский Голодомор ; Л. Ившина (общ. ред.), Н. Тысячная (сост.). Киев : ЗАО «Украинская пресс-группа», 2007. 208 с.

9. Корисні посилання щодо теми голодомору. URL: https://mon.gov.ua/ua/osvita/zagalna-serednyaosvita/korisni-posilannya-shodo-temi-golodomoru (дата звернення: 02.11.2020).

10. Заставний Ф. Український голодомор 1932-1933 років та його географія: через призму сучасної демографічної статистики. URL: https:// ukrhist.at.ua/publ/66-1-0-950 (дата звернення: 27.10.2020).

11. Людоедство во время голодомора. URL: https: / /nv.ua/ukraine/events/lyudoedstvo-vo-vremyagolodomora-istoricheskie-fakty-novosti-ukrainy-5005 5304.html (дата звернення: 09.11.2020).

12. Голодомор був навмисно спричинений Сталіним. URL: https: / / www. radiosvoboda.org/a/28756326. html (дата звернення: 09.11.2020).

13. Постанова ВЦВК і РНК СРСР «Про охорону майна державних підприємств, колгоспів і кооперативів та про зміцнення суспільної соціалістичної) власності». URL: http://territoryterror.org.ua/uk/archive/ photo-archive/photo/?pictureid=577 (дата звернення: 14.11.2020).

14. Сталин и Каганович. Переписка. 1931-1936 гг. / состав. О.В. Хлевнюк, Р.У. Дэвис, Л.П. Кошелева. Москва : РОССПЭН, 2001. 797 с.

15. Марочко В. Листування Й. Сталіна і Л. Кагановича у червні-серпні 1932 р.: технологія голодомору. Краєзнавство. 2013. № 4. С. 55-58.

Матвєєва Л. Г., доктор юридичних наук, дочент, завідувач кафедри теорії та філософії права факультету підготовки фахівців для органів досудового розслідування Одеського державного університету внутрішніх справ

Тарасенко Л. Б., кандидат історичних наук, дочент, професор кафедри теорії та філософії права факультету підготовки фахівців для органів досудового розслідування Одеського державного університету внутрішніх справ 